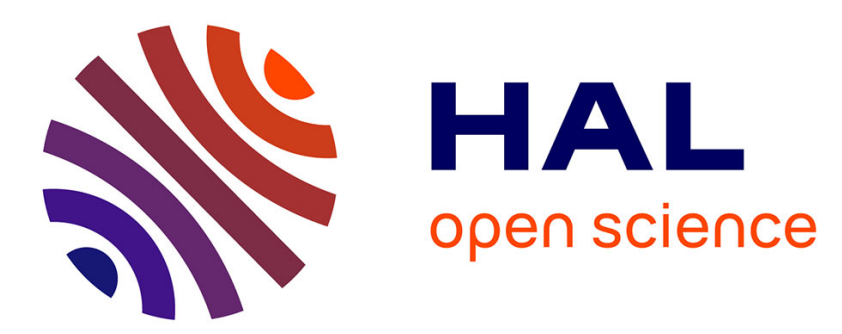

\title{
Propolis chemical composition and honeybee resistance against Varroa destructor
}

M. Popova, Maritza Regina Reyes-Carreno, Yves Le Conte, V. Bankova

\section{To cite this version:}

M. Popova, Maritza Regina Reyes-Carreno, Yves Le Conte, V. Bankova. Propolis chemical composition and honeybee resistance against Varroa destructor. Natural Product Research, 2014, 28 (11), pp.788-794. 10.1080/14786419.2014.8811366 . hal-02630043

\section{HAL Id: hal-02630043 \\ https://hal.inrae.fr/hal-02630043}

Submitted on 27 May 2020

HAL is a multi-disciplinary open access archive for the deposit and dissemination of scientific research documents, whether they are published or not. The documents may come from teaching and research institutions in France or abroad, or from public or private research centers.
L'archive ouverte pluridisciplinaire HAL, est destinée au dépôt et à la diffusion de documents scientifiques de niveau recherche, publiés ou non, émanant des établissements d'enseignement et de recherche français ou étrangers, des laboratoires publics ou privés. 


\title{
Propolis chemical composition and honeybee resistance against Varroa destructor
}

\author{
M. Popova ${ }^{\mathrm{a}}$, M. Reyes $^{\mathrm{b}}$, Y. Le Conte ${ }^{\mathrm{b}}$ and V. Bankova ${ }^{\mathrm{a} *}$ \\ ${ }^{a}$ Institute of Organic Chemistry with Centre of Phytochemistry, Bulgarian Academy of Sciences, Sofia, \\ Bulgaria; ${ }^{\circ}$ INRA, UR 406 Abeilles et Environnement, Site Agroparc, 84914 Avignon Cedex 9, France
}

(Received 9 December 2013; final version received 6 January 2014)

\begin{abstract}
Propolis is known as honeybee chemical defence against infections and parasites. Its chemical composition is variable and depends on the specificity of the local flora. However, there are no data concerning the relationship between propolis chemical composition and honeybee colony health. We tried to answer this question, studying the chemical composition of propolis of bee colonies from an apiary near Avignon, which are tolerant to Varroa destructor, comparing it with colonies from the same apiary which are non-tolerant to the mites. The results indicated that non-tolerant colonies collected more resin than the tolerant ones. The percentage of four biologically active compounds - caffeic acid and pentenyl caffeates - was higher in propolis from tolerant colonies. The results of this study pave the way to understanding the effect of propolis in individual and social immunity of the honeybees. Further studies are needed to clarify the relationship between propolis chemical composition and honeybee colony health.
\end{abstract}

Keywords: propolis; propolis constituents; Varroa destructor; Varroa-resistant colonies

\section{Introduction}

Propolis (bee glue) is a resinous material used by honeybees (Apis mellifera L.) in the construction and adaptation of their nests to fill out cracks in the hives. To produce propolis, bees collect plant resins and mix it with wax (Ghisalberti 1979). It is now generally accepted that bees collect resinous plant materials, produced by a variety of botanical processes in different parts of the plants. These are substances actively secreted by intact and wounded plants through their leaves, buds and mucilages (Crane 1988). The specificity of the local vegetation is responsible for the chemical composition of propolis: in different ecosystems bees collect propolis from different source plants, choosing appropriate representatives of the local flora (Bankova 2005). Propolis contains 'protective' secondary plant metabolites, which play an important role in preventing microbial infestation of vulnerable plant tissues; and thus possesses antimicrobial properties against different bacteria, fungi and viruses (Burdock 1998; Sforcin \& Bankova 2011).

It has been suggested that propolis plays a defensive role in the hive, too, but surprisingly, the studies dealing with the activity of propolis against bee pathogens are scarce. Recently, there is an emerging interest in the potential of propolis to combat bee pathogens (Garedew et al. 2002; Damiani et al. 2010; Simone-Finstrom \& Spivak 2012; Bilikova et al. 2013). A recent study of Simone et al. (2009) has revealed the role of propolis in bees' social immunity. In addition, some propolis constituents, such as $p$-coumaric acid, demonstrated the ability to up-regulate immunity

*Corresponding author. Email: bankova@orgchm.bas.bg 
genes in honeybees (Mao et al. 2013). However, none of the above-mentioned studies have considered the chemical composition of the studied propolis, while propolis chemical composition is highly variable. To date, there are no scientific data concerning the relationship between the health of the bee colonies and the chemical composition of their respective propolis.

Varroa mites were introduced to the European honeybee Apis mellifera over 30 years ago, and have since become the largest threat to apiculture around the world. It is known that a few subset populations of European honeybee races have been sustainably surviving mite infestation for periods over 10 years without mite control treatment (Fries et al. 2006; Le Conte et al. 2007). Such population exists in the area of Avignon, France, where Varroa-resistant honeybee colonies reduce the reproductive success of their infesting mites compared with local control colonies (Locke et al. 2012). Mechanistic explanations of the bees' ability to suppress mite reproductive success remain unknown to a large extent.

We studied the chemical composition of the propolis from resistant and susceptible colonies from Avignon from one and the same apiary in order to clarify whether there are any chemical differences in this defensive material, which might contribute to the resistance.

\section{Results and discussion}

The propolis extract obtained with $70 \%$ ethanol is known as balsam. It contains bioactive plant metabolites from plant resins, while undissolved matter is formed mainly from waxes and mechanic impurities. Balsam amount in propolis is characteristic of the amount of resin collected by the bees. The balsam content of the samples is presented in Table 1. The samples obtained from resistant colonies had significantly lower balsam content: 58\% compared with $72 \%$ for propolis from susceptible colonies $(p<0.05)$. This fact is an indication that bees from resistant colonies have allocated lesser resources to resin collection, than bees from susceptible colonies.

Over 60 individual constituents were identified completely or tentatively in each sample by gas chromatography/mass spectrometry (GC/MS) profiling (data not shown). The chemical profiles of all the samples were very similar in qualitative composition. These profiles can be presented in a concise form by the relative amounts of the main compound classes identified (Table 1): aromatic acids [main components (MC): benzoic, caffeic, $p$-coumaric acids], phenolic acid esters - coumarates, ferulates/isoferulates and caffeates; chalcones (MC: pinocembrin chalcone), flavones and flavonols (MC: chrysin and galangin), flavanones and dihydroflavonols (MC: pinocembrin, pinobanksin-3-O acetate); sugars, and others [fatty acids, triterpenes, and so on - all minor components under $0.5 \%$ of total ion current (TIC)]. In order to analyse the large amount of data, we applied principal component analysis (PCA). The PCA of the peak areas corresponding to each compound from both sample groups resulted in two groups correlated with their origin from mite-resistant and mite-susceptible colonies (Figure 1).

The chemical distinctions between propolis from resistant and susceptible colonies were less obvious than the ones in balsam percentage. The most important difference was the fact that relative concentration of caffeic acid and caffeic acid pentenyl esters: 3-methyl-3-butenyl caffeate, 2-methyl-2-butenyl caffeate and 3-methyl-2-butenyl caffeate (Figure 2) were higher in propolis of resistant colonies and the differences observed were statistically significant $(p<0.05)$ (Figure 3). Higher concentrations of two further caffeates, caffeic acid phenethyl ester (CAPE) and cinnamyl caffeate, were present in the samples from resistant colonies but the differences were not statistically significant. A possible explanation of these differences could be the difference in chemical profiles of the bud exudates collected by the resistant and the susceptible bee colonies.

It is important to note that caffeic acid and caffeates are among propolis components with pronounced and diverse biological properties. A mixture of CAPE, prenyl caffeates and benzyl 
Version définitive du manuscrit publiée dans / Final version of the manuscript published in :

Natural Product Research (2014), Vol. 28, N¹1, p. 788-794, DOI: 10.1080/14786419.2014.881366

Journal homepage: http://www.tandfonline.com/doi/full/10.1080/14786419.2014.881368

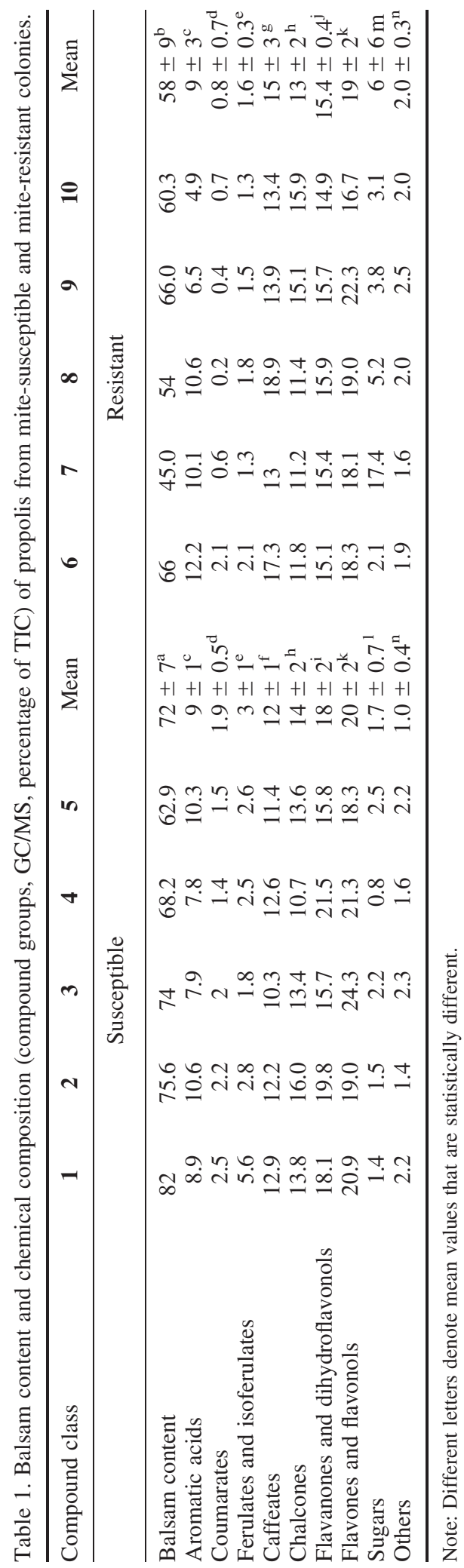


Version définitive du manuscrit publiée dans / Final version of the manuscript published in :

Natural Product Research (2014), Vol. 28, N¹1, p. 788-794, DOI: 10.1080/14786419.2014.881366

Journal homepage: htip:ilNy/vi tandfonline.com/doi/full/10.1080/14786419.2014.881366

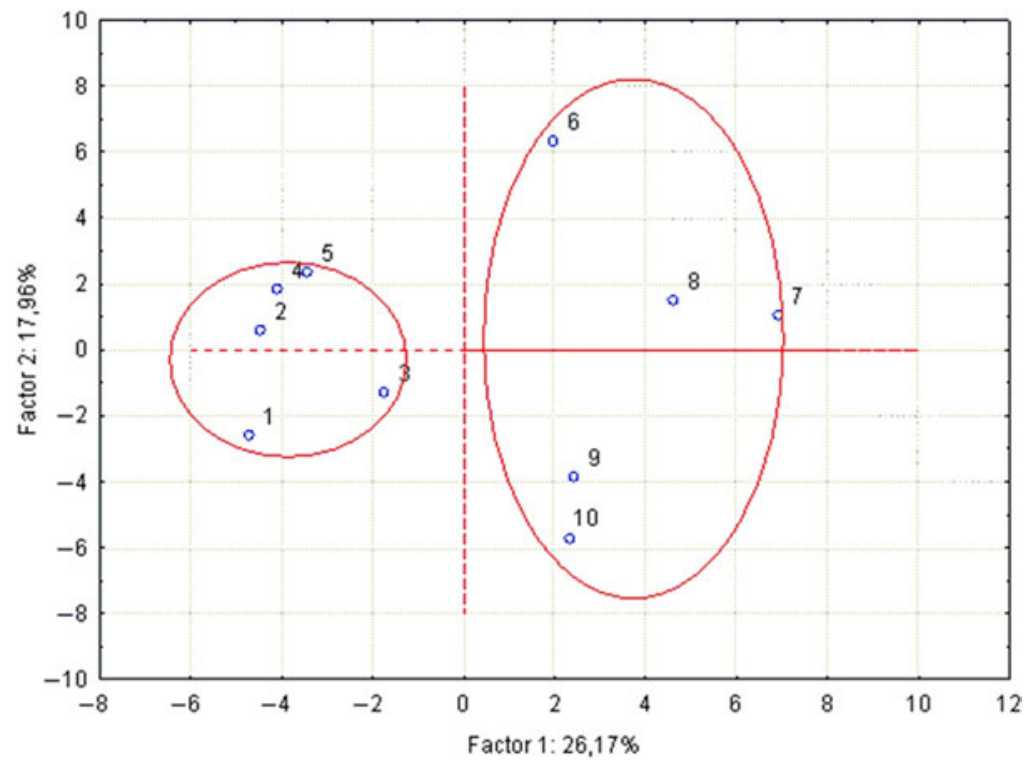

Figure 1. PCA of propolis secondary metabolite profiles from resistant and susceptible colonies. 1-5, samples from mite-susceptible colonies; 6-10, samples from mite-resistant colonies.

caffeate was recently found to inhibit the growth of the bee pathogen Paenibacillus larvae, the causal agent of American foulbrood (Bilikova et al. 2013). The way in which these compounds affect the health of the colony is yet to be established. They might possess acaricidic activity or have the potential to strengthen the immune responses of honeybees. The compounds in question might affect the surviving potential of the bee colonies in yet another way: it could be speculated that those propolis constituents which are in higher concentration in bee glue of resistant colonies might have favourable effect on the respective colonies by reducing the damage caused by Varroa-vectored viruses (Le Conte et al. 2010). Further studies have to be performed in order to clarify whether any of those factors or a combination of them is of importance for the Varroa resistance of the colonies.<smiles>O=C(C=Cc1ccc(O)c(O)c1)OCCc1ccccc1</smiles>

Phenethyl caffeate (CAPE)<smiles>CC(C)=CCOC(=O)C=Cc1ccc(O)c(O)c1</smiles><smiles>O=C(O)/C=C/c1ccc(O)c(O)c1</smiles>

Caffeic acid<smiles>O=C(/C=C/c1ccc(O)c(O)c1)OC/C=C/c1ccccc1</smiles>

Cinnamyl caffeate<smiles>C=C(C)CCOC(=O)/C=C/c1ccc(O)c(O)c1</smiles><smiles>CC=C(C)COC(=O)C=Cc1ccc(O)c(O)c1</smiles>

2-methyl-2-butenyl caffeate

Figure 2. Plant metabolites found in higher concentration in propolis from resistant colonies. 


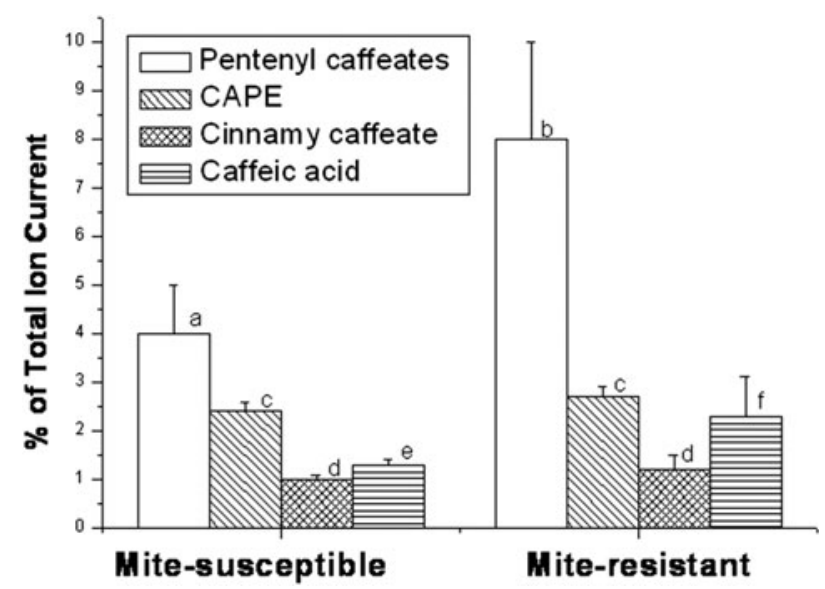

Figure 3. Content of caffeic acid derivatives in propolis from Avignon - mite-resistant and mitesusceptible colonies. Bars with the same letters are not statistically different from each other.

\section{Experimental}

\subsection{Propolis}

Propolis was collected in May-June 2012 in an apiary near Avignon, from five mite-susceptible and five mite-resistant colonies.

\subsection{Chemicals}

The following standards were used for the identification of compounds by GC/MS: benzoic, cinnamic, caffeic, $p$-coumaric, ferulic acids and vanillin were purchased from Merck; pinocembrin, chrysin and galangin were purchased from Extrasynthese, France; pinobanksin and pinobanksin acetate were previously isolated in our lab. CAPE, pentenyl caffeates, benzyl caffeate, benzyl and phenethyl ferulate, pentenyl ferulates, were synthesised in our lab previously.

\subsection{Balsam content}

Propolis samples were extracted with $70 \%$ ethanol. Propolis was powdered; an exact measured sample of $0.5 \mathrm{~g}$ was dissolved in $15 \mathrm{~mL} 70 \%$ ethanol in a $25 \mathrm{~mL}$ flask and left for $24 \mathrm{~h}$ at room temperature. It was then filtered, and the procedure was repeated. The extracts were filtered (paper filter), combined and diluted to $50 \mathrm{~mL}$ with $70 \%$ ethanol in a volumetric flask. For each sample, three parallel extractions were performed. From each of the parallel extracts, $2 \mathrm{~mL}$ was evaporated in vacuo to dryness to constant weight $g$. The percentage of balsam $P$ in propolis sample $(M-$ weight of the propolis sample) was calculated by the formula

$$
P=\frac{50 g}{2 M} 100 \%
$$

The mean of the three values was determined.

\subsection{Sample preparation for GC/MS analysis}

From each sample, after evaporation of the abovementioned extract to dryness, about $5 \mathrm{mg}$ of the dry residue were mixed with $50 \mu \mathrm{L}$ of dry pyridine and $75 \mu \mathrm{L}$ of N,O-bis-(trimethylsilyl)- 
trifluoroacetamide (BSTFA) and heated at $80^{\circ} \mathrm{C}$ for $20 \mathrm{~min}$. The standard compounds were subjected to the same procedure for silylation as about $1 \mathrm{mg}$ of the pure compound was mixed with $10 \mu \mathrm{L}$ of dry pyridine and $15 \mu \mathrm{L}$ of BSTFA. The silylated ethanolic extracts and reference compounds were analysed by GC/MS.

\subsection{GC/MS analysis}

The GC/MS analysis was performed with a Hewlett-Packard gas chromatograph 5890 series II plus (Hewlett-Packard, Palo Alto, CA, USA) equipped with a $30 \mathrm{~m}$ long, $0.25 \mathrm{~mm}$ i.d. and $0.5 \mu \mathrm{m}$ film thickness HP5-MS capillary column, linked to a Hewlett-Packard 5972 mass spectrometer system (Hewlett-Packard, Palo Alto, CA, USA). The temperature was programmed from 60 to $300^{\circ} \mathrm{C}$ at a rate of $5^{\circ} \mathrm{C} / \mathrm{min}$, and a 10 - min hold at $300^{\circ} \mathrm{C}$. Helium was used as a carrier gas at a flow rate of $0.8 \mathrm{~mL} / \mathrm{min}$. The split ratio was $1: 10$, injector temperature $280^{\circ} \mathrm{C}$, interface temperature $300^{\circ} \mathrm{C}$, ionisation voltage $70 \mathrm{eV}$. Identification of the compounds was performed using comparison of mass spectra and retention times of reference compounds ( 21 compounds), and the rest was tentatively identified using their mass spectra and retention time analysis. The semi-quantification was carried out by internal normalisation with the area of each compound. The addition of individual areas of the compounds corresponds to $100 \%$ area.

\subsection{Statistical analysis}

Multivariate analysis of propolis chemical profiles was performed by PCA, using the GC/MS data for the identified compounds expressed as a percentage of the TIC, respectively. Statistica Version 8.0 was used for the analyses.

\section{Conclusions}

The results of this study pave the way in the understanding of the effect of propolis in the honeybee immunity and give another example of the ability of honeybees to modulate their behaviour to improve their social immunity. Further studies need to be carried out to understand the relationship between the chemical composition of propolis and honeybee colony health.

\section{Acknowledgements}

This study was supported by the European Union-funded 7th Framework Project BEE DOC, Grant Agreement 244956 and the Bulgarian Science Fund, Contract DKOF 7RP 02/15. The authors are thankful to Dr. Daniela Antonova for running the GC/MS.

\section{References}

Bankova V. 2005. Chemical diversity of propolis and the problem of standardization. J Ethnopharmacol. 100:114-117. Bilikova K, Popova M, Trusheva B, Bankova V. 2013. New anti-Paenibacillus larvae substances purified from propolis. Apidologie. 44:278-285.

Burdock GA. 1998. Review of the biological properties and toxicity of bee propolis (propolis). Food Chem Toxicol. 3(6):347-363.

Crane E. 1988. Beekeeping: science, practice and world recourses. London: Heinemann.

Damiani N, Fernández NJ, Maldonado LM, Álvarez AR, Eguaras MJ, Marcangeli JA. 2010. Bioactivity of propolis from different geographical origins on Varroa destructor (Acari: Varroidae). Parasitol Res. 107:31-37.

Fries I, Imdorf A, Rosenkranz P. 2006. Survival of mite infested (Varroa destructor) honey bee (Apis mellifera) colonies in a Nordic climate. Apidologie. 7:1-7.

Garedew A, Lamprecht I, Schmolz E, Schricker B. 2002. The varroacidal action of propolis: a laboratory assay. Apidologie. 33:41-50. 
Version définitive du manuscrit publiée dans / Final version of the manuscript published in :

Natural Product Research (2014), Vol. 28, N¹1, p. 788-794, DOI: 10.1080/14786419.2014.881366

Journal homepage: http://www.tandfonline.com/doi/full/10.1080/14786419.2014.881368

Ghisalberti EL. 1979. Propolis: a review. Bee World. 60:59-84.

Le Conte Y, de Vaublanc G, Crauser D, Jeanne F, Rousselle JC, Bécards JM. 2007. Honey bee colonies that have survived Varroa destructor. Apidologie. 38:566-572.

Le Conte Y, Ellis M, Ritter W. 2010. Varroa mites and honey bee health: can Varroa explain part of the colony losses? Apidologie. 41:353-363.

Locke B, Le Conte Y, Crauser D, Fries I. 2012. Host adaptations reduce the reproductive success of Varroa destructor in two distinct European honey bee populations. Ecol Evol., doi:101002/ece3248.

Mao W, Schuler MA, Berenbaum MR. 2013. Honey constituents up-regulate detoxification and immunity genes in the western honey bee Apis mellifera. Proc Natl Acad Sci U S A. 110:8842-8846.

Sforcin JM, Bankova V. 2011. Propolis: is there a potential for the development of new drugs? J Ethnopharmacol. 133:253-260.

Simone M, Evans JD, Spivak M. 2009. Resin collection and social immunity in honey bees. Evolution. 63:3016-3022.

Simone-Finstrom M, Spivak M. 2012. Increased resin collection after parasite challenge: a case of self-medication in honey bees? PLoS One. 7:e34601. 